\title{
Update on the assessment of magnesium status
}

\author{
Maurice J. Arnaud* \\ The Beverage Institute for Health \& Wellness, The Coca-Cola Company, PO Box 1734, Atlanta, GA 30301, USA
}

Magnesium (Mg) is the fourth most abundant mineral in the body and the most abundant intracellular divalent cation, with essential roles in many physiological functions. Consequently, the assessment of $\mathrm{Mg}$ status is important for the study of diseases associated with chronic deficiency. In spite of intense research activities there is still no simple, rapid, and accurate laboratory test to determine total body Mg status in humans. However, serum $\mathrm{Mg}<0.75 \mathrm{mmol} / \mathrm{l}$ is a useful measurement for severe deficiency, and for values between 0.75 and $0.85 \mathrm{mmol} / \mathrm{l}$ a loading test can identify deficient subjects. The loading test seems to be the gold standard for $\mathrm{Mg}$ status, but is unsuitable in patients with disturbed kidney and intestinal functions when administered orally. There is also a need to reach a consensus on a standardized protocol in order to compare results obtained in different clinical units. Other cellular $\mathrm{Mg}$ measurements, such as total or ionized $\mathrm{Mg}$, frequently disagree and more research and systematic evaluations are needed. Muscle Mg appears to be a good marker, but biopsies limit its usefulness, as is the case with bone Mg, the most important but heterogeneous $\mathrm{Mg}$ compartment. The development of new and non invasive techniques such as nuclear magnetic resonance (NMR) may provide valuable tools for routinely analysing ionized $\mathrm{Mg}$ in tissues. With the development of molecular genetics techniques, the recent discovery of Transient Receptor Potential Melastatin channels offers new possibilities for the sensitive and rapid evaluation of Mg status in humans.

Loading test: Serum: Erythrocyte: Lymphocytes: Muscle: Bone: Ionized Mg

Magnesium (Mg) is the fourth most abundant mineral in the body, and the most abundant intracellular divalent cation, and is essential for a diverse range of physiological functions. $\mathrm{Mg}$ deficiency, either from inadequate intake, excess excretion or altered homeostasis, is often suspected to be associated with the initiation of many symptoms and diseases ${ }^{(1)}$. In spite of its multiple and ubiquitous roles, $\mathrm{Mg}$ status can be assessed in severe deficiency and a large number of studies have investigated various markers during nutritionally induced or pathological mild and chronic deficiency. A review published in 1991 stated that the assessment of Mg status was difficult as there was no simple, rapid and accurate test to indicate total body $\mathrm{Mg}$ status ${ }^{(2)}$. More recently, another review indicated that whilst functional and/or biological markers are available for many nutrients, there is still a need for indicators to specifically diagnose $\mathrm{Mg}$ deficiency ${ }^{(3)}$. Another difficulty associated with $\mathrm{Mg}$ is related to its metabolism. It is known that the equilibrium and exchange of $\mathrm{Mg}$ between body compartments and tissue pools occurs slowly, so determining $\mathrm{Mg}$ concentration in one tissue may not provide information about $\mathrm{Mg}$ status in another. This review provides the most up-to-date information on the assessment of $\mathrm{Mg}$ status.

\section{Metabolism}

The metabolism of $\mathrm{Mg}$ and its body distribution have been investigated in animals and humans using the radioactive isotope ${ }^{28} \mathrm{Mg}^{(4,5)}$ but its use is limited by the short half-life of 21 hours, and for human studies by exposure to radiation. Thus, ${ }^{25} \mathrm{Mg}$ and ${ }^{26} \mathrm{Mg}$ stable isotopes have been used in human to accurately assess $\mathrm{Mg}$ absorption, excretion, bioavailability, pool sizes, and turnover. However, the relatively high abundance of the isotopes used $\left(10.13 \%\right.$ for ${ }^{25} \mathrm{Mg}$ and $11.17 \%$ for ${ }^{26} \mathrm{Mg}$ ) imposes the administration of doses of $\mathrm{Mg}$ for analytical precision that may be absorbed and eliminated dose dependently. The mean biological half-life of $\mathrm{Mg}$ has been estimated to be between 41 and 181 days $^{(6,7)}$. These values are consistent with the observation that it takes 3 months to normalize a $20 \%$ depletion of body $\mathrm{Mg}$ stores $^{(8)}$.

\section{Compartments}

Observations from stable isotope studies in children and adolescents indicate that it is not possible to directly relate $\mathrm{Mg}$ deficiency to changes in the exchangeable pool size or pool turnover ${ }^{(9)}$. In adults, compartmental analysis has shown that only $25 \%$ of total body $\mathrm{Mg}$ can be studied using stable isotopes, i.e. that which rapidly exchanges between the plasma compartment and two extra-plasma pools. Consequently, the majority of total body $\mathrm{Mg}$ escapes this analysis and is transferred to long-term storage pools, particularly bone ${ }^{(10)}$ where approximately half the body's $\mathrm{Mg}$ content $(1 \mathrm{~mol})$ is found. Less than $1 \%$ of total body $\mathrm{Mg}$ is present in blood, with approximately $0.3 \%$ in serum $^{(2)}$. 


\section{Biomarkers and tests for status assessment}

\section{Serum}

Blood samples must be prepared carefully to prevent $\mathrm{Mg}$ contamination with anticoagulant, and generally blood concentrations are determined in serum rather than plasma. Haemolysis can increase the $\mathrm{Mg}$ concentration because erythrocytes contain more $\mathrm{Mg}$ than serum. In addition to sample preservation, a survey of the quality of the measurements of routine laboratories has been performed and it was concluded that these sources of error are significant and may reduce the diagnostic potential of serum total $\mathrm{Mg}^{(11)}$.

Serum $\mathrm{Mg}$ concentrations are dependent on dietary intake and intestinal absorption as well as kidney function. Kidney filtration and reabsorption are essential to maintain stable serum levels between 0.75 and $0.96 \mathrm{mmol} / 1$, a range observed for healthy adult subjects. Serum $\mathrm{Mg}$ concentration is the most frequently performed analysis, and whilst some studies have found correlations between serum and tissues values $^{(12,13)}$ others have not ${ }^{(14-16)}$. Bone is the primary storage site for both calcium and $\mathrm{Mg}$, and provides a labile pool for the release of $\mathrm{Mg}$ to maintain serum concentrations. Decreases in serum $\mathrm{Mg}$ can be observed when drugs are taken, particularly diuretics. Otherwise, lower serum $\mathrm{Mg}$ values indicate deficiency and impaired metabolic control as observed in diabetes, renal tubular disorders, alcoholism and malabsorption. By comparison, higher serum values are observed when subjects take $\mathrm{Mg}$ medication such as Mg-rich antacids or cathartics ${ }^{(17)}$ or in the case of renal failure. In conclusion, serum values lower or higher than the $0.75-0.96 \mathrm{mmol} / 1$ range require diagnosis and treatment; but values in the normal range also do not rule out the possibility of total body deficit compensated for by the release of $\mathrm{Mg}$ from the bone pool.

Diabetes and obesity. Hypomagnesaemia has been reported in type 2 diabetes but after 3 -months of treatment with $30 \mathrm{mmol} /$ day given orally, the values increased from $0.73 \pm 0.8$ to $0.81 \pm 0.1 \mathrm{mmol} / \mathrm{l}$, equivalent to control group concentrations $^{(18)}$. A comparison of serum $\mathrm{Mg}$ concentrations in 109 type 2 diabetics with 156 age- and sex-matched healthy controls in Switzerland showed significantly lower values for the diabetic subjects, $0.77 \pm 0.08$ and $0.83 \pm 0.07 \mathrm{mmol} / \mathrm{l}$, respectively. Serum $\mathrm{Mg}$ concentrations were below the normal reference range in $37.6 \%$ of the diabetic patients and $10.9 \%$ of the control subjects $(P<0.001)$. This study highlights the fact that serum $\mathrm{Mg}$ concentrations indicate that poor $\mathrm{Mg}$ status is common in type 2 diabetics in Switzerland ${ }^{(19)}$.

In obese patients, a significant negative correlation was found between waist-to-hip ratios and serum $\mathrm{Mg}$ concentrations, whilst no such correlation was observed for either erythrocyte or platelet $\mathrm{Mg}^{(20)}$.

Heart disease. In patients with end-stage heart disease and $\mathrm{Mg}$ stores highly depleted, an intravenous administration of $64 \mathrm{mmol} \mathrm{Mg}$ significantly increased serum $(0.68 \pm 0.06$ to $0.82 \pm 0.3 \mathrm{mmol} / \mathrm{l})$, erythrocyte (1.44 \pm 0.3 to $1.75 \pm 0.4 \mathrm{mmol} / \mathrm{l})$ and lymphocyte $\mathrm{Mg}$ $(1.23 \pm 0.7$ to $1.52 \pm 0.8 \mu \mathrm{g} / \mathrm{mg}$ of protein) and also total urinary $\mathrm{Mg}$ excretion $(3.4 \pm 1.27$ to $17.5 \pm 8.1 \mathrm{mmol})$. These changes observed after the 24-hour infusion of $\mathrm{Mg}$ ascorbate were all highly significant ${ }^{(21)}$
Crohn's disease. After intravenous infusion of $60 \mathrm{mmol} \mathrm{Mg}$ to subjects with Crohn's disease, a significant increase in serum and mononuclear cell $\mathrm{Mg}$ concentrations was observed in addition to an increased muscle and body retention ${ }^{(22)}$.

Asthma. Mg status has been evaluated in healthy subjects and those with mild to moderate asthma. Measurements included total and ionized serum and erythrocyte $\mathrm{Mg}$ and the retention of an intravenous $\mathrm{Mg}$ load. The results showed that total serum $\mathrm{Mg}$ offers a useful clinical diagnostic tool and that ionized $\mathrm{Mg}$ is closely correlated but does not offer any diagnostic advantages ${ }^{(23)}$.

In conclusion, serum analysis is useful for the determination of $\mathrm{Mg}$ status in deficient subjects with pathologies leading to increased urinary excretion. In patients seen for routine medical care at an urban family centre, there was a $20 \%$ overall prevalence of hypomagnesaemia among this predominantly female African American population ${ }^{(24)}$. However, this observation did not rule out a higher prevalence of deficiency which could only be characterized by the measurement of low tissue $\mathrm{Mg}$.

\section{Blood cells}

\section{Erythrocytes}

Normal erythrocytes contain a high concentration of $\mathrm{Mg}$ ions that are essential for ATP function and other metabolic processes ${ }^{(25)}$. The Mg content of erythrocytes has been shown to decrease in humans provided with low $\mathrm{Mg}$ diets. These changes were only observed after several weeks of low dietary intake, the delay being attributed to the erythrocyte pool which reflects long-term rather than current nutrient status ${ }^{(26)}$.

Diabetes and obesity. In non-insulin type 2 diabetics, both serum and intracellular ionized erythrocyte $\mathrm{Mg}$ concentration was significantly lower compared with non diabetic control subjects. Oral supplementation for 8 weeks with $400 \mathrm{mg} / \mathrm{d}$ $\mathrm{Mg}$ restored erythrocyte concentrations to normal values without changing serum concentrations ${ }^{(27)}$. Lower values of $\mathrm{Mg}$ in erythrocytes have also been reported in type 1 diabetics compared with control subjects $(1.41 \pm 0.56$ v. $2.94 \pm 1.12 \mathrm{mmol} /$ 1 , respectively), while serum concentrations were similar and urinary $\mathrm{Mg}$ excretion significantly elevated in the diabetic group $^{(28)}$. A one year oral $\mathrm{Mg}$ supplementation study, with a daily dose of $13 \mathrm{mmol}(300 \mathrm{mg}$ ) as $\mathrm{Mg}$ gluconate, in type 1 diabetic patients characterized by low erythrocyte $\mathrm{Mg}$ $(<2.3 \mathrm{mmol} / \mathrm{l})$ significantly increased these values from $2.03 \pm 0.03$ to $2.48 \pm 0.12 \mathrm{mmol} / \mathrm{l}$ while serum $\mathrm{Mg}$ levels did not change: 0.73 and $0.77 \mathrm{mmol} / \mathrm{l}^{(29)}$. A recent study performed on diabetic children reports that erythrocyte $\mathrm{Mg}$ levels showed an inverse correlation with percentage of retained $\mathrm{Mg}$ load. Although erythrocyte and serum $\mathrm{Mg}$ were significantly lower in diabetic children compared with controls, serum $\mathrm{Mg}$ concentrations were in the normal range in both groups. The authors suggest that erythrocyte $\mathrm{Mg}$ measurement is preferred to serum $\mathrm{Mg}$ and that the load test is a reliable and sensitive method ${ }^{(30)}$.

In a group of normotensive obese patients, erythrocyte and platelet $\mathrm{Mg}$ concentrations, but not serum, were significantly lower than in healthy controls ${ }^{(20)}$.

Migraine. Total Mg levels in plasma, erythrocytes and lymphocytes were analyzed in a group of 29 migraine patients 
and 18 control subjects. At baseline, results showed significantly lower concentrations of total erythrocyte $\mathrm{Mg}$ in migraine patients compared with controls $(50 \cdot 7 \pm 4.7 v$. $52.9 \pm 4.7 \mathrm{mg} / \mathrm{l})$. Migraine patients then received a daily supplement of 11 mineral water containing $110 \mathrm{mg} / \mathrm{l} \mathrm{Mg}$ for 2 weeks, which resulted in a significant increase in erythrocyte $\mathrm{Mg}$ concentrations from $50.7 \pm 4.7$ to $52.9 \pm 4.7 \mathrm{mg} / \mathrm{l}$ with no observed effect on plasma $\mathrm{Mg}^{(31)}$.

Chronic fatigue syndrome. Shorter-term effects of intramuscular Mg administration given every week for 6 weeks to patients with chronic fatigue syndrome showed a significant increase in erythrocyte $\mathrm{Mg}$ concentrations (+0.57 $\pm 0.192 \mathrm{mmol} / \mathrm{l})$. This study raises an important methodological problem. The erythrocyte $\mathrm{Mg}$ concentrations were different in two groups of patients with chronic fatigue syndrome, 1.29 and $1.60 \mathrm{mmol} / \mathrm{l}$, whilst a normal range of $1.41-2.09 \mathrm{mmol} / \mathrm{l}$ have been suggested. This important difference was explained by the fact that the measurements were undertaken in different laboratories and under different conditions ${ }^{(32)}$. Although it is known that $\mathrm{Mg}$ slowly leaches out of red cells into the plasma, the length of sample storage time could not explain the differences observed.

Critical illness. From a study in critically ill postoperative patients and healthy controls, the best $\mathrm{Mg}$ parameter to measure hypo- or hypermagnesaemia was ionized $\mathrm{Mg}$ in erythrocytes when compared with total erythrocyte $\mathrm{Mg}$ and total ionized serum $\mathrm{Mg}$. The prevalence of hypomagnesaemia was $15.9 \%$ from the measurement of total serum $\mathrm{Mg}, 22.2 \%$ from ionized serum $\mathrm{Mg}$ and $36.5 \%$ from ionized $\mathrm{Mg}$ in erythrocytes, a level almost twice as high as that observed in total or ionized serum $\mathrm{Mg}^{(33)}$.

Asthma. Since low Mg intake has been associated with airway hyper-responsiveness, a study was undertaken in 49 asthmatic patients in which $\mathrm{Mg}$ in erythrocytes, serum and urine was measured. The results showed lower erythrocyte and urine $\mathrm{Mg}$ as compared with healthy controls whereas serum concentrations did not differ ${ }^{(15)}$

Healthy subjects and genetic control. It has been observed that intra-individual variations in plasma and red blood cell $\mathrm{Mg}$ concentrations over long time periods are small when compared with inter-individual variations. The analysis of family resemblance for $\mathrm{Mg}$ concentrations in serum and erythrocytes, based on data from nuclear families and twins showed that while adult plasma $\mathrm{Mg}$ varies linearly with age, erythrocyte $\mathrm{Mg}$ shows a non-linear trend: quadratic for males and fifth degree polynomial for females. Univariate and bivariate model analyses of these results strongly suggested that genetic factors were primarily responsible for the observed family resemblance and that one common genetic factor alone could not explain all the correlations ${ }^{(34)}$. Further analysis under a mixed model yielded significant support for a major gene effect on erythrocyte $\mathrm{Mg}$, but not on plasma $\mathrm{Mg}$. Parameter estimates indicated that the data are compatible with a common major gene for elevated erythrocyte $\mathrm{Mg}$. About $5 \%$ of the population appeared homozygous for this gene and nonfamilial factors account for a small fraction of the total variance ${ }^{(35)}$. Genetic factors controlling intra- and extracellular $\mathrm{Mg}$ levels were shown amongst unrelated adult male blood donors to be composed of at least three components: the major histocompatibility complex (HLA and H-2)-associated genes, the non-major histocompatibility complex genes, and tissue factors modulating the respective importance of the first two sets of factors ${ }^{(36)}$.

Studies performed on mice demonstrated that animals selected for low and high $\mathrm{Mg}$ levels exhibited significant different total $(25.1 v .18 .0 \mathrm{mg} / \mathrm{l})$ and ionized $(11.8 v .9 .1 \mathrm{mg} / \mathrm{l})$ plasma $\mathrm{Mg}$, total erythrocyte $\mathrm{Mg}(54.5$ v. $40.7 \mathrm{mg} / \mathrm{l})$ and decreased tibia $(4.45$ v. $3.56 \mathrm{mg} / \mathrm{g})$ and kidney $(955 v$. $869 \mathrm{mg} / \mathrm{kg}$ ) Mg concentrations. They also had a higher urinary excretion and changes in the size and exchange rates of other compartmental pools. The population examined were the second generation between 4 inbred strains, and pairs with the highest and the lowest erythrocyte $\mathrm{Mg}$ concentrations were selected for reproduction. After the same selection for 18 consecutive generations, erythrocyte $\mathrm{Mg}$ values diverged rapidly and regularly and remain constant. These two strains were homozygote for all the relevant alleles ${ }^{(37,38)}$. It was also shown that the genetic impact was not only observed with erythrocytes but also affects total body $\mathrm{Mg}$ metabolism ${ }^{(37)}$. Today, with the discovery and progress in transient receptor potential-melastatin (TRPM) research, we anticipate that a better understanding of the genetic expression at the cellular and tissue levels of these channels controlling epithelial $\mathrm{Mg}$ transport will explain the differences observed in $\mathrm{Mg}$ homeostasis.

In spite of this genetic regulation, the $\mathrm{Mg}$ content of erythrocytes has been studied as an index of $\mathrm{Mg}$ status in 20 healthy women with erythrocyte $\mathrm{Mg}$ concentrations below the 15th percentile $(\leq 1.97 \mathrm{mmol} / \mathrm{l})$. Supplementation of $250 \mathrm{mg} /$ day $\mathrm{Mg}$ for 3 weeks resulted in an increase in erythrocyte $\mathrm{Mg}$ concentration of only $1.6 \%$ while plasma Mg level was significantly increased by $5.3 \%$. The authors concluded that erythrocyte $\mathrm{Mg}$ is not a useful measurement for monitoring the effect of $\mathrm{Mg}$ supplementation in individuals ${ }^{(39)}$. This opinion is shared by others ${ }^{(40)}$ although it has been reported that a $10 \%$ lower erythrocyte $\mathrm{Mg}$ concentration in adults with marginal deficiency was restored to normal values after 2 weeks of supplementation with $15.6 \mathrm{mmol} \mathrm{Mg}(360 \mathrm{mg})$ as Mg pyrrolidone carboxylate ${ }^{(41)}$.

Low $\mathrm{Mg}$ diet in healthy subjects. The effect of a low $\mathrm{Mg}$ intake $(112 \mathrm{mg} /$ day $)$ for 92 days preceded and followed by control periods of 35 and 49 days with a daily supplement of $200 \mathrm{mg}$ showed a significant decrease of $\mathrm{Mg}$ in erythrocytes and muscle and a higher $\mathrm{Mg}$ retention ${ }^{(16)}$. These study protocols with induced deficiency and recovery in healthy subjects are effective to test both kinetic and quantitative changes in $\mathrm{Mg}$ cell and tissue pools as well as in urine. With further data, these intervention studies will allow the validation of status biomarkers by demonstrating their sensitivity and specificity for measuring $\mathrm{Mg}$ status.

\section{Leukocytes}

In both animal and human studies, the $\mathrm{Mg}$ content of white blood cells such as lymphocytes was shown to be a better index of intracellular $\mathrm{Mg}$ in skeletal and cardiac muscle ${ }^{(42,43)}$. It was even stated ${ }^{(44)}$ that lymphocytes have advantages over other tissues, such as erythrocytes and muscle, for assessing intracellular $\mathrm{Mg}$ because during experiments on $\mathrm{Mg}$ deficient rats, the magnitude of the Mg loss from lymphocytes was similar to that of cardiac and skeletal muscle.

Diabetes and obesity. Mg was analyzed in plasma, mononuclear cells, erythrocytes, urine and in muscle biopsies from 
25 subjects with type 1 diabetes and the results were compared with those of 28 healthy controls. $\mathrm{Mg}$ in mononuclear cells was suggested to be an index of intracellular $\mathrm{Mg}$ and a significant correlation between muscle and mononuclear cells was reported in patients ${ }^{(45)}$.

Crohn's disease. After intravenous infusion of $60 \mathrm{mmol}$ $\mathrm{Mg}$ to 30 subjects with Crohn's disease, a significant increase in the $\mathrm{Mg}$ concentrations in mononuclear cells $(65-94 \%$ lymphocytes, $5-30 \%$ monocytes, $0-3 \%$ basophilic cells and $0-1 \%$ granulocytes) was observed along with increases in plasma, muscle and an increased body retention of $\mathrm{Mg}$. However, the authors concluded that the analysis of muscle $\mathrm{Mg}$ and an estimation of $\mathrm{Mg}$ retention during an intravenous infusion are superior markers for confirming suspected $\mathrm{Mg}$ deficiency ${ }^{(22)}$.

Migraine. In migraine patients, mononuclear blood cell $\mathrm{Mg}$ concentrations were significantly lower than in controls subjects $(8.52 \pm 3.64, \quad 7.93 \pm 2.84$ and $10.6 \pm 3.38 \mathrm{mg} / \mathrm{d}$ DNA, respectively) ${ }^{(46)}$. Total $\mathrm{Mg}$ levels in plasma, lymphocytes and erythrocytes and ionized $\mathrm{Mg}$ in lymphocytes were analyzed in a group of 29 migraine patients and 18 control subjects. Results showed significantly lower concentrations of ionized lymphocyte $\mathrm{Mg}(12.0 \pm 3.5$ v. $14.2 \pm 3.8 \mathrm{mg} / \mathrm{l})$ and total $\mathrm{Mg}$ in erythrocytes $(50.7 \pm 4.7$ v. $53.5 \pm 2.9 \mathrm{mg} / \mathrm{l})$ in migraine patients compared with controls. After a 2 week daily supplementation with 11 of mineral water containing $110 \mathrm{mg} / \mathrm{l} \mathrm{Mg}$, a significant increase in all intracellular $\mathrm{Mg}$ concentrations with no effect on plasma $\mathrm{Mg}$ was observed in migraine patients. Among the analyzed parameters, ionized lymphocyte $\mathrm{Mg}$ appeared to be the most sensitive index of $\mathrm{Mg}$ deficiency with a $15 \%$ decrease in migraine patients when compared with controls and a $16 \%$ increase after 2 weeks of a Mg-rich mineral water intake ${ }^{(31)}$.

Hypertension and heart disease. $\mathrm{Mg}$ content in lymphocytes and skeletal muscle biopsies from 28 subjects demonstrated no significant correlation between these values except in a group of three normal volunteers and nine patients with mild arterial hypertension ${ }^{(47)}$. Another study showed that total intracellular $\mathrm{Mg}$ content was significantly lower in lymphocytes from hypertensive patients compared with healthy subjects $(0.07 \pm 0.03$ v. $0.11 \pm 0.04 \mathrm{mmol} / \mathrm{g}$ protein $)$ while serum and erythrocyte $\mathrm{Mg}$ and ionized platelet $\mathrm{Mg}^{(48)}$ were not significantly different.

Patients with congestive heart failure experienced cardiac arrhythmias due to digitalis toxicity. Although serum $\mathrm{Mg}$ concentrations were within normal ranges lymphocyte content was decreased, suggesting the existence of cellular $\mathrm{Mg}$ depletion. Intravenous bolus administration of $\mathrm{Mg}$ sulphate, followed by intramuscular $\mathrm{Mg}$ repletion, abolished the digitalis-toxic arrhythmia ${ }^{(49)}$.

Critical illness. Because the $\mathrm{Mg}$ content of mononuclear blood cells was suggested to be a better index of $\mathrm{Mg}$ status than serum concentrations, these measurements were performed in critically ill patients who were either moderately or severely hypomagnesaemia ( $\geq 0.4$ to $\leq 0.6 \mathrm{mmol} / \mathrm{l}$ and $\leq 0.4 \mathrm{mmol} / \mathrm{l}$, respectively) and receiving a 24-hour intravenous $\mathrm{Mg}$ replacement therapy $(0.5$ and $0.75 \mathrm{mmol} / \mathrm{kg}$ of intravenous $\mathrm{Mg}$ sulfate, respectively). Serum concentrations increased significantly from baseline to $48 \mathrm{~h}(0.5 \pm 0.1$ to $0.8 \pm 0.2 \mathrm{mmol} / \mathrm{l})$ while intracellular $\mathrm{Mg}$ content did not change significantly within the study period $(2.6 \pm 1.0$ to
$3.0 \pm 1.3 \mathrm{fmol} / \mathrm{cell})$. In this group of trauma patients from an Intensive Care Unit, serum $\mathrm{Mg}$ was a better index of $\mathrm{Mg}$ status than mononuclear blood cell $\mathrm{Mg}^{(50)}$.

Healthy subjects. Although Mg deficiency has been diagnosed using low Mg levels in leucocytes, their concentration varies according to the pathology and the study population ${ }^{(40)}$. Some studies do not find a correlation between mononuclear blood cells, such as monocytes and lymphocytes, and serum or erythrocyte $\mathrm{Mg}$. A 2-fold larger inter-individual coefficient of variation for the $\mathrm{Mg}$ content of mononuclear blood cells than for serum and erythrocytes introduced by the separation step and washing of the cells may explain the lack of correlation ${ }^{(51)}$.

\section{Platelets}

Diabetes, obesity and hypertension. The concentration of $\mathrm{Mg}$ in platelets has been measured in two groups of normotensive and hypertensive type 2 diabetic patients and in healthy subjects. Plasma and erythrocyte $\mathrm{Mg}$ concentrations were significantly lower in the diabetic patients. The concentrations of $\mathrm{Mg}$ in platelets were lower in patients but the difference was significant only for the the hypertensive diabetics ${ }^{(52)}$. Later, this research group showed that both microalbuminuria and proteinuria in type 1 diabetic patients was associated with altered $\mathrm{Mg}$ homeostasis and a negative correlation was found between glycated haemoglobin and both plasma and platelet $\mathrm{Mg}^{(53)}$. These studies do not demonstrate that platelets are a more sensitive and specific marker of $\mathrm{Mg}$ status. However, in another study performed on obese normo- or hypertensive patients, platelet $\mathrm{Mg}$ was significantly reduced compared with controls. However, other parameters were also significantly decreased such as $\mathrm{Mg}$ in plasma and in erythrocytes. The conclusion of the authors ${ }^{\text {(20) }}$ was that intra platelet $\mathrm{Mg}$ assay was more reliable than the dosage of ionize $\mathrm{Mg}$ by NMR. Although the study did not investigate platelets, ionized $\mathrm{Mg}$ in erythrocytes showed similar but less striking changes in normotensive and hypertensive obese subjects when compared with non-insulin-dependent diabetes ${ }^{(54)}$.

\section{Buccal cells}

In a study investigating the effects of various $\mathrm{Mg}$ levels in drinking water in healthy subjects, $\mathrm{Mg}$ was determined in muscle biopsies and in sublingual mucous membrane cells. A negative correlation was found between muscle and sublingual cell $\mathrm{Mg}$ suggesting that these cells cannot be used to evaluate intracellular $\mathrm{Mg}$ status ${ }^{(55)}$. More studies are needed to evaluate whether these cells, which require non-invasive collection procedures, can provide valuable information. Contamination from $\mathrm{Mg}$ in saliva or the salivary microbiota and previously ingested beverages or water can affect the results and must be controlled.

\section{Tissues}

\section{Bone and teeth}

There are more experimental studies in animals than in humans on the effects of $\mathrm{Mg}$ deficient diets on bone. Rats fed a diet providing a surfeit of $\mathrm{Mg}$ and 2 others diets resulted 
in two degrees of $\mathrm{Mg}$ deficiency. While the recommended $\mathrm{Mg}$ dose is $40 \mathrm{mg} / 100 \mathrm{~g}$ dry diet, the control group of this study received $150 \mathrm{mg} / 100 \mathrm{~g}$ and the two groups with deficiency received either a diet without $\mathrm{Mg}$ for one week or $5 \mathrm{mg} /$ $100 \mathrm{~g}$ for 2 weeks. There was no consistent difference between the $\mathrm{Mg}$ concentrations found in liver, heart, or skeletal muscle of Mg-deficient and control rats, but bone accurately reflected the level of dietary $\mathrm{Mg}$. However, there was a significant difference between the $\mathrm{Mg}$ concentration of the anterior and posterior halves of the ribs, indicating irregular distribution of $\mathrm{Mg}$ within the bone. There were also significant differences in the $\mathrm{Mg}$ concentration of different bones from the same animals. Therefore one entire bone, such as the sternum or the rib, should be analysed ${ }^{(56)}$. Weanling rats fed six levels of dietary $\mathrm{Mg}$, ranging from 0 to $150 \mathrm{mg} / 100 \mathrm{~g}$ purified diet, showed a linear decrease in $\mathrm{Mg}$ retention with increased bone $\mathrm{Mg}$. As a negative relationship was found between $\mathrm{Mg}$ retention following the load test and the level of dietary $\mathrm{Mg}$, the load test appears to be an acceptable means of indirectly assessing $\mathrm{Mg}$ status provided there is normal renal and cardiovascular status and normal water balance ${ }^{(57)}$. In a more recent study, it was observed that mice selected for their low $\mathrm{Mg}$ status had reduced total and ionized plasma $\mathrm{Mg}$, and lower erythrocyte, tibia and kidney $\mathrm{Mg}$ levels ${ }^{(37)}$.

A study on a 2-month-old boy with congenital hypomagnesaemia has been published in which $\mathrm{Mg}$ concentrations were measured at 8 and 12 years of age in milk teeth lost naturally and the values compared with those of healthy control children ${ }^{(58)}$. A significantly lower $\mathrm{Mg}$ content was found in teeth, 4.80 v. $6.82 \pm 0.77 \mathrm{mg} / \mathrm{g}$ dry weight and 4.12 v. $6.18 \pm \mathrm{mg} / \mathrm{g}$ dry weight at 8 and 12 years old respectively compared with controls. However, a greater significant difference was observed at 12 years for serum $(0.60 \pm 0.02$ v. $0.86 \pm 0.02 \mathrm{mmol} / \mathrm{l})$, erythrocyte $(1.55 \pm 0.04$ v. $2.20 \pm 0.15 \mathrm{mmol} / \mathrm{l})$, and lymphocyte $\operatorname{Mg}(1.42 \pm 0.14$ v. $3.72 \pm 0.41 \mathrm{fmol} / \mathrm{cell})$. Similar differences were found at 8 years of age demonstrating that dental $\mathrm{Mg}$ is potentially interesting for the evaluation of calcified tissues ${ }^{(58)}$. In adult subjects, $\mathrm{Mg}$ concentrations in serum and bone were significantly reduced in a patient with chronic hypomagnesaemia. However, as reported previously in animals, $\mathrm{Mg}$ in bone is not homogeneously distributed and the values measured are dependent on sampling. It was shown that $30 \%$ of bone $\mathrm{Mg}$ is in a surface limited pool present either within the hydration shell or on the crystal surface. The larger fraction of bone $\mathrm{Mg}$ was shown not to be associated with bone matrix but rather to be an integral part of the bone crystal. The authors concluded that the major factor determining $\mathrm{Mg}$ concentration in bone would appear to be the serum $\mathrm{Mg}_{\text {level }}{ }^{(59)}$. In a study of the same group where muscle, erythrocyte and bone $\mathrm{Mg}$ were measured in patients with reduced, normal and increased $\mathrm{Mg}$ levels, a highly significant correlation between serum and bone $\mathrm{Mg}$ was reported. The authors' conclusion was that bone $\mathrm{Mg}$ in man increased during $\mathrm{Mg}$ excess and decreased during $\mathrm{Mg}$ depletion ${ }^{(12)}$. The invasive sampling and the heterogeneous distribution of $\mathrm{Mg}$ in bone are the reasons why there is limited knowledge on the metabolism of $\mathrm{Mg}$ in bone.

\section{Muscle}

A quarter of total body $\mathrm{Mg}$ is located in muscle. This tissue is a significant compartment and seems appropriate to assess $\mathrm{Mg}$ status, however, the limited number of studies is explained by the need to perform invasive biopsies.

Heart disease. The $\mathrm{Mg}$ retention test used together with muscle biopsies in 5 patients with acute myocardial infarction (MI) and 6 healthy controls demonstrated a significantly higher mean retention of $42 \%$ in the MI group compared with $22 \%$ in the control group. A lower muscle content of $\mathrm{Mg}$ in the MI group supported the results of the retention test and indicated $\mathrm{Mg}$ deficiency ${ }^{(60)}$.

Crohn's disease. Mg status was evaluated in 30 subjects with Crohn's disease and 30 healthy controls. Subjects with Crohn's disease had significantly lower concentrations of $\mathrm{Mg}$ in muscle, mononuclear cells, and $24 \mathrm{~h}$ urine collections compared with controls. A significant increase in muscle, mononuclear cells, and plasma $\mathrm{Mg}$ concentrations was observed following intravenous infusion of $60 \mathrm{mmol} \mathrm{Mg}$ into the Crohn's disease patients. The retention of the infused $\mathrm{Mg}$ was significantly higher in subjects with Crohn's disease than in 11 healthy controls and was inversely correlated with muscle $\mathrm{Mg}$ content. The most sensitive measurements of $\mathrm{Mg}$ status and deficiency were the analysis of $\mathrm{Mg}$ in muscle and the estimation of $\mathrm{Mg}$ retention ${ }^{(22)}$.

Lung disease. Muscle biopsies and serum samples have been taken in patients with chronic obstructive pulmonary disease and acute respiratory failure and $\mathrm{Mg}$ measurements showed that $10 \%$ of the patients had hypomagnesaemia $(<0.7 \mathrm{mmol} / \mathrm{l})$ with normal muscle values $(44 \mathrm{mmol} / \mathrm{kg}$ of fat-free solids), whereas low muscle values were found in $47 \%$ of patients with normal serum Mg levels. As no significant correlation was observed between serum and muscle $\mathrm{Mg}$, the authors concluded that serum $\mathrm{Mg}$ levels are of little value in the diagnosis of intracellular $\mathrm{Mg}$ deficits ${ }^{(61)}$.

Asthma. Skeletal muscle biopsies have been taken in asthmatics with and without oral $\beta_{2}$-agonists and $\mathrm{Mg}$ concentrations compared with healthy subjects. Muscle $\mathrm{Mg}$ was lower in the asthmatics both with and without oral $\beta_{2}$-agonists $(3.62 \pm 0.69$ and $3.43 \pm 0.60$ v. $4.43 \pm 0.74 \mathrm{mmol} /$ $100 \mathrm{~g}$, respectively) while serum $\mathrm{Mg}$ was not different with the controls ${ }^{(62)}$

Low $\mathrm{Mg}$ diet in healthy subjects. A more recent study compared the effect of a low $\mathrm{Mg}$ intake $(112 \mathrm{mg} / \mathrm{day})$ for 92 days preceded by a control period of 35 days where they received a daily supplement of $200 \mathrm{mg}$ and followed by the same supplementation for 49 days. During the restriction periods skeletal muscle $\mathrm{Mg}$ decreased significantly (53.4 \pm 1.2 and $51.6 \pm 1.3 v .48 .1 \pm 1.3 \mathrm{mmol} / \mathrm{kg}$ dry weight), as did erythrocyte $\mathrm{Mg}(6.74 \pm 0.08$ and $6.68 \pm 0.08$ v. $5.91 \pm 0.07 \mu \mathrm{mol} / \mathrm{g}$ haemoglobin) and $\mathrm{Mg}$ retention from $\mathrm{Mg}$ balance $(+32$ and $+38 v .-42 \mathrm{mg} /$ day). There was a non-significant decrease of serum $\mathrm{Mg}$ during the restriction period confirming the lack of sensitivity of this measurement ${ }^{(16)}$.

Healthy subjects. Measurements of muscle $\mathrm{Mg}$ were undertaken in biopsies taken from 49 individuals living in two Swedish cities with 5.7 and $1.7 \mathrm{mg} \mathrm{Mg} / \mathrm{litre}$ in the local drinking water. There were significantly higher skeletal muscle $\mathrm{Mg}$ concentrations $(4.1 \pm 0.2$ v. $3.9 \pm 0.3 \mathrm{mmol} /$ $100 \mathrm{~g}$ fat-free dry weight) in subjects living in the area with the higher water $\mathrm{Mg}$ content. Dietary $\mathrm{Mg}$ intakes obtained from questionnaires were similar in the two groups, suggesting that muscle $\mathrm{Mg}$ content is a sensitive marker of $\mathrm{Mg}$ status ${ }^{(63)}$. However, another study from this research group did not 
confirm these results ${ }^{(55)}$. No correlation between muscle and erythrocyte $\mathrm{Mg}$ was reported ${ }^{(64)}$. However, overall these results suggest that measurements of muscle $\mathrm{Mg}$ may be considered to be a reliable indicator of $\mathrm{Mg}$ status ${ }^{(65)}$.

In conclusion, more research is needed but muscle biopsies cannot provide a non-invasive method to assess $\mathrm{Mg}$ status.

\section{Total, ionized $\mathrm{Mg}$}

Although $\mathrm{Mg}$ is either bound, in particular to protein, or free/ ionized, only total $\mathrm{Mg}$ was able to be measured before ion-selective electrodes, fluorescent probes or nuclear magnetic resonance (NMR) were developed to identify and quantify this biological active form. Measurements of ionized $\mathrm{Mg}$ concentration were first undertaken in the 1970s on the axoplasm of squid axons ${ }^{(66)}$ and then on muscle ${ }^{(67)}$ and biological fluid ${ }^{(68)}$. Errors resulting from changes in electrolyte composition, electrolyte interactions and interferences in the electrode response were investigated at that time ${ }^{(69)}$. Many studies and publications only deal with the intra-method differences ${ }^{(70,71)}$ in results, and errors in the analysis of ionized $\mathrm{Mg}^{(72-75)}$.

Diabetes. Low ionized $\mathrm{Mg}$ defined as serum concentrations lower that $0.46 \mathrm{mmol} / \mathrm{l}$ has been shown to be highly prevalent in diabetic subjects ${ }^{(76)}$.

Kidney disease. In haemodialysis patients, the values of ionized and total $\mathrm{Mg}$ in serum and mononuclear blood cells and total $\mathrm{Mg}$ in erythrocytes were shown to be significantly increased compared with a control population ${ }^{(77)}$. However, total serum $\mathrm{Mg}$ was not increased. In these patients, the two ionized $\mathrm{Mg}$ markers did not offer any advantages and total $\mathrm{Mg}$ concentration in serum remains the measurement of choice.

Critical illness. In critically ill children, ionized serum $\mathrm{Mg}$ was significantly lower than in a healthy group of children $(0.37 \pm 0.10$ v. $0.46 \pm 0.03 \mathrm{mmol} / \mathrm{l})$. Many critically ill children exhibit ionized hypomagnesaemia with normal total serum $\mathrm{Mg}$ concentrations and these children would not be recognized as $\mathrm{Mg}$-deficient based on routine total serum $\mathrm{Mg}$ tests $^{(14)}$.

Healthy subjects. In a study of healthy volunteers, the mean whole blood ionized $\mathrm{Mg}$ concentration was $0.52 \mathrm{mmol} / \mathrm{l}$ with a range of 0.44 to $0.59 \mathrm{mmol} / \mathrm{l}$ and an ionized $\mathrm{Mg} /$ total serum $\mathrm{Mg}$ ratio of 0.60 and a range of $0.50-0.69^{(78)}$. A positive correlation between ionized and serum total $\mathrm{Mg}$ was observed in 160 healthy children and the ratio was $58 \cdot 3 \pm 4 \cdot 1 \%{ }^{(79)}$. There appears to be no demonstrable advantage to measuring ionized $\mathrm{Mg}$ as opposed to total $\mathrm{Mg}$ for evaluating $\mathrm{Mg}$ status.

\section{Fluorescent probes}

Fluorescent probes have made it possible to measure cytosolic free $\mathrm{Mg}$ using a two-excitation wavelength fluorometer. The probe penetrates the plasma membrane as an ester that is hydrolyzed in the cytosol, and a microscope connected to the fluorometer is used to measure the fluorescence ratio at two excitation wavelengths in individual cells. The probe Mag-Furan-2 has been mainly used for measurements in platelets, whilst; Mag-Indo-1 has been used to assess cytosolic free $\mathrm{Mg}$ in mononuclear blood cells and erythrocytes. When fluorescent probes are used in ex vivo samples, the conservation of the sample is of major importance and validation of the method is necessary. Mag-Indo- 1 has been used to determine the concentration of ionized Mg in lymphocytes of 29 migraine patients and 18 control subjects. The stability of lymphocytes in blood collected in either sodium citrate or heparin, during the isolation and staining process as well as the homogenous fluorescence distribution were tested to evaluate the reproducibility of the measurements. While there was no difference for total $\mathrm{Mg}$ in lymphocytes, significantly lower values were found for ionized $\mathrm{Mg}$ in migraine patients compared to controls, and after a 2 week $\mathrm{Mg}$ supplementation with $7 \cdot 4-12 \mathrm{mmol} \mathrm{Mg} / \mathrm{d}$ from mineral water $(170-275 \mathrm{mg} / \mathrm{d})$ the concentrations of ionized $\mathrm{Mg}$ in lymphocytes of migraine patients increased to those of the control subjects. In this study ionized intracellular $\mathrm{Mg}$ was a sensitive index to detect a deficit and the effect of a supplementation $^{(31)}$. Using the same fluorescent probe, the effect of $\mathrm{Mg}$ supplementation on healthy volunteers showed a significant increase in ionized $\mathrm{Mg}$ in lymphocytes after 2 days with unchanged total $\mathrm{Mg}$ in lymphocytes. After 4 days supplementation, ionized $\mathrm{Mg}$ returned to the initial value while total $\mathrm{Mg}$ concentrations in lymphocytes increased significantly ${ }^{(80)}$. Intracellular ionized $\mathrm{Mg}$ concentrations have been measured in platelets using the fluorescent probe Furaptra ${ }^{(69)}$.

Another promising technique is nuclear magnetic resonance (NMR). After blood sample measurements, the next consideration is non-invasive analysis of superficial body tissues, such as the skin and muscle. After the first determination of ionized $\mathrm{Mg}$ concentrations in human erythrocytes by ${ }^{31} \mathrm{P}$ NMR spectroscopy ${ }^{(81)}$, this technique was applied to measurements of intracellular erythrocyte $\mathrm{Mg}$ adenosine triphosphate and free $\mathrm{Mg}^{(25)}$. Ionized $\mathrm{Mg}$ has also been analyzed in human blood plasma using ${ }^{31} \mathrm{P}$ magnetic resonance spectroscopy with the addition of a ligand so that free and bound $\mathrm{Mg}$ have different resonances. The results showed that the magnetic resonance spectroscopy methods gave higher values for free ionized $\mathrm{Mg}$ than values obtained by ion-selective electrodes ${ }^{(82)}$. With in vivo ${ }^{31} \mathrm{P}$ NMR spectroscopy, intracellular free $\mathrm{Mg}$ in skeletal muscle and brain tissues was studied in 30 young volunteers after one month of daily supplementation with $12 \mathrm{mmol} \quad \mathrm{Mg} \quad(0.62 \pm 0.05 \quad$ v. $\quad 0.71 \pm 0.03 \mathrm{mmol} / \mathrm{l}$, respectively). Only urinary excretion was increased and the distribution of $\mathrm{Mg}$ in brain tissue, and muscle and also in serum and erythrocytes was unchanged in these healthy young subjects apparently without $\mathrm{Mg}$ deficiency ${ }^{(83)}$. This non invasive technique had previously demonstrated similar intracellular free $\mathrm{Mg}$ concentrations in skeletal muscle and brain tissues, approximately $0.3 \mathrm{mmol}^{(84)}$. Skeletal muscle ionized $\mathrm{Mg}$ was measured with NMR in women over the course of one complete menstrual cycle. There was no evidence of a menstrual cycle effect on muscle ionized $\mathrm{Mg}$ or total $\mathrm{Mg}$ in serum, erythrocytes and mononuclear blood cells ${ }^{(85)}$. NMR brain and muscle in vivo measurement in children with migraine showed that brain intracellular ionized $\mathrm{Mg}$ concentrations were reduced by $25 \%$ in patients; $0 \cdot 139 \pm 10$ v. $0 \cdot 186 \pm 26 \mathrm{mmol}$, respectively ${ }^{(86)}$. Recently, a noninvasive intracellular technique for ionized $\mathrm{Mg}$ measurements has been developed using energy dispersive X-ray microanalysis ${ }^{(87)}$.

In conclusion, these non-invasive methods are still in being developed and are not available to clinical laboratories, but in 
the future they may become the most efficient and accurate way to routinely measure intracellular ionized $\mathrm{Mg}$.

\section{Hair and nails}

\section{Hair}

The potential use of hair to assess $\mathrm{Mg}$ status is an attractive idea as it is the least invasive sampling procedure, and samples can be taken over a long period of time and can be stored until the analysis can be performed.

Cattle and animal studies. It has been reported that cattle suffering from grass tetany have blood serum $\mathrm{Mg}$ concentrations below $10 \mathrm{mg} /$ litre compared with a mean normal value of $21 \mathrm{mg} / \mathrm{l}^{(88)}$; a higher $\mathrm{Mg}$ content was found in the hair of cattle when diet was supplemented with $\mathrm{Mg}$. However, no difference was found in hair analyzed five times during the year (to determine seasonal effects) or in the $\mathrm{Mg}$ content of hair from cows with grass tetany ${ }^{(89)}$. In rats fed diets containing either 82 or $17 \mathrm{mg} / 100 \mathrm{~g}$, significant changes in the $\mathrm{Mg}$ contents of various hair fractions were observed after 2 or 3 months ${ }^{(90)}$.

Methods. As hair can be contaminated by the environment, it is necessary to wash it before analysis. The effects of washing hair on its $\mathrm{Mg}$ content have been studied. The methods selected were a detergent wash, a hexane-ethanol wash and an acetone-ether detergent wash. There was a significant difference between various washing procedures, but it was shown that the $\mathrm{Mg}$ content was less than half that of the unwashed hair. These results demonstrate that $\mathrm{Mg}$ in hair is an unreliable sample to assess $\mathrm{Mg}$ status ${ }^{(91)}$.

Human. In end stage heart disease patients with significantly lower plasma and erythrocyte $\mathrm{Mg}$ levels, a lower $\mathrm{Mg}$ content was also found in hair $(26.7 \pm 15 \cdot 3 \mu \mathrm{g} / \mathrm{g})$ compared with healthy control subjects $(54.5 \pm 19.8 \mu \mathrm{g} / \mathrm{g})$. The authors explained this exceptionally low content in hair by a chronic disturbance of $\mathrm{Mg}$ metabolism ${ }^{(21)}$. Hair $\mathrm{Mg}$ concentrations in patients with Fibromyalgia were significantly higher compared with those of healthy subjects $(84.7 \pm 73.3 v$. $46 \cdot 8 \pm 28.9 \mu \mathrm{g} / \mathrm{g}$ ). As no other biomarker of $\mathrm{Mg}$ status was measured and no quality control procedures described, these results must be interpreted with caution ${ }^{(92)}$. In a 2-month-old boy with congenital hypomagnesaemia, hair $\mathrm{Mg}$ concentrations were measured at 8 and 12 years of age and compared with control healthy children with the same brown hair colour. Surprisingly, the $\mathrm{Mg}$ content of hair at 8 and 12 years was higher compared with controls: $164 \pm 8.08$ v. $52.7 \pm 21.7$ and $244 \pm 11.5 v .121 .6 \pm 27.2 \mu \mathrm{g} / \mathrm{g}$ dry weight, respectively. Other trace element concentrations such as manganese, copper and zinc were also higher in hair. The authors concluded that hair acts as a sink for oligo elements, including $\mathrm{Mg}$ and did not reflect the severe deficiency as seen through the significantly low values for serum, erythrocyte, lymphocyte and teeth $^{(58)}$. Analysis of hair and serum $\mathrm{Mg}$ in neonates and their mothers showed a negative correlation between maternal hair and ionized $\mathrm{Mg}$ in cord serum, and male neonates had higher levels of $\mathrm{Mg}$ in cord blood and hair than females ${ }^{(93)}$. These researchers also investigated the effect of two $\mathrm{Mg}$ multivitamin supplements given for 3 months (each tablet contained $24 \mathrm{mg} \mathrm{Mg}$ ) and 4 months (tablets containing $100 \mathrm{mg} \mathrm{Mg}$ ) at a dose of $7 \mathrm{mg} \mathrm{Mg}$ per $\mathrm{kg}$ body weight and per day in 46 children aged 2-6 years. The results showed that hair $\mathrm{Mg}$ concentrations increased significantly from $7.74 \pm 0.36$ to $11.03 \pm 0.89 \mu \mathrm{g} / \mathrm{g}$ dry mass. This increase was observed in 40 children out of the 46 recruited, suggesting that 3 months $\mathrm{Mg}$ supplementation was effective for increasing $\mathrm{Mg}$ hair concentrations in children ${ }^{(94)}$.

\section{Nails}

The mean loss of nail substance is approximately $3 \mathrm{~g}$ per year and the ratio between calcium and $\mathrm{Mg}$ is about 4.5/1 with some variability due to external adsorption ${ }^{(95)}$. The reproducibility over a 6-year period of the measurement in toenails of 16 trace elements, including $\mathrm{Mg}$ has been reported from 127 women in the United States. Toenail concentrations of some minerals can be used as biomarkers of exposure and a single sample may represent long-term exposure for toxic intakes of nutrients. For $\mathrm{Mg}$, the mean value $\pm \mathrm{SD}$ was $167 \pm 130 \mu \mathrm{g} / \mathrm{g}$ and was fourth most abundant after sulphur, calcium and chlorine ${ }^{(96)}$.

In conclusion, from these studies, there is a need to validate the measurement of both hair and nail $\mathrm{Mg}$ and to demonstrate that the sample represents a period of either deficient or excessive $\mathrm{Mg}$ intake. Up to now, it is unclear how to interpret $\mathrm{Mg}$ values found in hair or nail.

\section{Physiological tests}

\section{Loading test}

Balance studies are time consuming, labour intensive and need well trained staff. They are often performed in a metabolic unit and require complete urine and faecal collections; therefore it is not a method that can be applied as a routine test for the evaluation of $\mathrm{Mg}$ status. Loading tests are simplified balance studies where absorption is supposed not to be disturbed when $\mathrm{Mg}$ is given orally so that body retention is calculated from urine elimination. $\mathrm{Mg}$ administration during a loading test can be either oral or intravenous and it is important that the subjects have normal kidney function. Urine is collected for 24 hours following administration of the $\mathrm{Mg}$ load as $\mathrm{Mg}$ excretion by the kidney has been shown to have a circadian rhythm ${ }^{(97)}$. Under these conditions, the loading test is supposed to be a reliable indicator of $\mathrm{Mg}$ status ${ }^{(65)}$.

Alcoholics. Retention of a low dose of $\mathrm{Mg}, 0.2 \mathrm{mEq} / \mathrm{kg}$ lean body weight, given intravenously has been assessed in hypomagnesaemia patients and normomagnesaemic alcoholics. It was shown that they retained significantly higher amounts of the $\mathrm{Mg}$ load than normal subjects. After parenteral $\mathrm{Mg}$ repletion, the retention was normalized showing that this test is a more sensitive index of $\mathrm{Mg}$ deficiency than serum concentration $^{(98)}$.

Crohn's and coeliac disease. In Crohn's disease patients, the most sensitive measurement of $\mathrm{Mg}$ status and deficiency has been shown to be the analysis of $\mathrm{Mg}$ in muscle and also the estimation of $\mathrm{Mg}$ retention ${ }^{(22)}$. A 12-hour intravenous $\mathrm{Mg}$ loading test $\left(30 \mathrm{mmol} / 1.73 \mathrm{~m}^{2}\right)$ was used in children and adolescents with coeliac disease to evaluate the frequency of $\mathrm{Mg}$ deficiency. The cut-off level for tissue $\mathrm{Mg}$ deficiency was identified at the point when $\mathrm{Mg}$ retention was greater than $40 \%$ of the load ${ }^{(99)}$. 
Critical illness. A study was performed to assess the value of intracellular $\mathrm{Mg}$ in erythrocytes and mononuclear blood cells in critically ill patients sub-divided into $\mathrm{Mg}$ depleted and non-depleted groups according to their response to a loading test. There were no significant difference between the $\mathrm{Mg}$ depleted and non-depleted groups (plasma 0.81 and $0.90 \mathrm{mmol} / 1$ and red blood cell 2.34 and $2.18 \mathrm{mmol} / 1$, mononuclear blood cell 25.16 and $18.1 \mathrm{mmol} / \mathrm{kg}$ dry weight, respectively). Thus, normal values of plasma, erythrocyte or mononuclear blood cell concentrations of $\mathrm{Mg}$ cannot exclude $\mathrm{Mg}$ depletion $^{(13)}$. Mg deficiency was identified in critically ill patients using a loading test and was validated using measurements of serum ionized $\mathrm{Mg}$. There was a significant increase in both serum ionized and total $\mathrm{Mg}$ concentrations by $43 \%$ and $59 \%$, respectively on day 1 compared with the control group. Urinary $\mathrm{Mg}$ excretion also increased after a load of $30 \mathrm{mmol}$ from $4.8 \pm 2.3 \mathrm{mmol} /$ day during the 3-day study period to $22.7 \pm 10.9 \mathrm{mmol} /$ day. The patients with an excretion lower than $70 \%$ of the total $\mathrm{Mg}$ were designated as functionally $\mathrm{Mg}$-deficient retainers and patients who excreted more than $70 \%$ were non-retainers. Interestingly, the number of retainers on day 2 was ten patients and only six on day 3 , indicating a replenishment of body $\mathrm{Mg}$ stores. In the retainer group, only two patients had a low serum ionized $\mathrm{Mg}$ concentration, while two other patients had low total serum $\mathrm{Mg}$ values. These results show that the $\mathrm{Mg}$-loading test is effective and serum ionized $\mathrm{Mg}$ appears to be an insensitive biochemical marker of functional hypomagnesemia ${ }^{(100)}$

Chronic fatigue syndrome. In a study population of 93 patients with unexplained chronic fatigue, only three subjects had plasma $\mathrm{Mg}$ concentrations lower than $0.6 \mathrm{mmol} / \mathrm{l}$ $(0.82 \pm 0.10 \mathrm{mmol} / \mathrm{l})$ and normal erythrocyte $\mathrm{Mg}$ $(1.97 \pm 0.22 \mathrm{mmol} / \mathrm{l})$. The $\mathrm{Mg}$ deficient group was identified from $\mathrm{Mg}$ retentions following an intravenous loading test with a four hour $\mathrm{Mg}$ infusion of $0.2 \mathrm{mEq} / \mathrm{keg}$ body weight. Patients with $20 \%$ or more $\mathrm{Mg}$ retention were diagnosed as moderately deficient and those with $50 \%$ or more as severely deficient. When $20 \%$ retention was taken as the cut-off value, $47 \%$ of the patients were classified as being Mg deficient ${ }^{(101)}$.

Asthmatic. In asthmatics, a significantly increased retention of $\mathrm{Mg}$ was observed in $58.9 \%$ of the patients after a loading test compared with $8.9 \%$ in normal subjects ${ }^{(15)}$.

Renal transplant. A one-hour intramuscular or intravenous infusion of $0.1 \mathrm{mmol} \mathrm{Mg}$ per $\mathrm{kg}$ body weight over 1 hour followed by a $24 \mathrm{~h}$ urine collection was designed for outpatients. Serum and urinary $\mathrm{Mg}$ were analyzed and the percentage retention before and after 4 months daily supplementation containing $5 \mathrm{mmol} \mathrm{Mg}$ showed a significant decrease from $47 \pm 43$ in patients after renal transplantation to $16 \pm 26$. Thus, Mg supplementation successfully returned the percentage retention towards normal values after 4 months. In the placebo group of patients after renal transplantation, the percentage retention was $58 \pm 27$. Retention of $20 \%$ of the dose or more was considered evidence of deficiency. These high levels of retention are greater than the mean $\pm 3 \mathrm{SD}$ of the control group and thus indicate $\mathrm{Mg}$ deficiency in spite of normal serum $\mathrm{Mg}$ level. The analysis of bone samples obtained from another group of patients undergoing hip replacement showed that short term $\mathrm{Mg}$ retention reflects femur$\mathrm{Mg}$ content, the most relevant $\mathrm{Mg}$ store. In this study ${ }^{(102)}$, dietary intake, faecal excretion and basal urinary $\mathrm{Mg}$ output were ignored and may explain the negative percentage retention values in healthy individuals. These data are however comparable with those obtained with $30 \mathrm{mmol}(810 \mathrm{mg}) \mathrm{Mg}$ infused over 8 hours ${ }^{(103)}$.

Low $\mathrm{Mg}$ diet in healthy subjects. Recently, a double blind crossover study evaluated the effect of moderate $\mathrm{Mg}$ deprivation in postmenopausal women receiving either $4.4 \mathrm{mmol}$ $(107 \mathrm{mg}) \mathrm{Mg}$ from a basal diet or $13.45 \mathrm{mmol}(327 \mathrm{mg})$ with a $\mathrm{Mg}$ supplement of $9.5 \mathrm{mmol}(220 \mathrm{mg})$ added for 72 days. $\mathrm{Mg}$ deprivation significantly reduced the positive $\mathrm{Mg}$ balance when the supplement was given, decreased red blood cell membrane $\mathrm{Mg}$, increased the calcium balance, decreased the faecal excretion of phosphorus and increased its urinary excretion, and decreased the urinary excretion of potassium. The authors suggest that a non-positive $\mathrm{Mg}$ balance and decreased red blood cell membrane concentration may be indicators of $\mathrm{Mg}$ deprivation ${ }^{(104)}$.

Healthy subjects. Mg status has been measured in healthy subjects by either oral or infused $\mathrm{Mg}$ loading tests and deficiencies have been diagnosed with this test, while serum $\mathrm{Mg}$ was not affected ${ }^{(105-107)}$. In one study urine was collected for 24 hours after an 8-hour infusion of $30 \mathrm{mmol} \mathrm{Mg}$. The data demonstrated a $\mathrm{Mg}$ retention of 28 and $6 \%$ of the dose in elderly and younger subjects respectively, suggesting a higher prevalence of $\mathrm{Mg}$ deficiency in the elderly. It was concluded that a significant sub-clinical $\mathrm{Mg}$ deficit was present in these healthy elderly subjects that was not detected by serum $\mathrm{Mg}^{(108)}$. Their study also showed that a 3-week daily oral $\mathrm{Mg}$ supplementation with $9 \mathrm{mmol} \mathrm{Mg}$ improved $\mathrm{Mg}$ status as shown by increased urinary excretion and lower body retention However, a parenteral loading test using $\mathrm{Mg}$ chloride $(0.206 \mathrm{mmol} / \mathrm{kg}$ body weight $)$ did not show any correlation between $\mathrm{Mg}$ retention and basal urinary excretion of $\mathrm{Mg}$ and plasma or erythrocyte $\mathrm{Mg}$ concentrations. This study raises the important point of the need to standardize the loading test procedure in order to produce the most sensitive and reproducible results ${ }^{(109)}$. The impact on $\mathrm{Mg}$ status of consuming drinking water of differing $\mathrm{Mg}$ content $(1.6 \mathrm{mg}$ and $25 \mathrm{mg} / \mathrm{l}$ ) for 6 weeks has been evaluated using an oral $\mathrm{Mg}$ loading test (575 $\mathrm{mg}$ of $\mathrm{Mg}$ ) administered in tablet form. The 24-hour urinary excretion of $\mathrm{Mg}$ was expressed as total $\mathrm{Mg}$ excretion and the $\mathrm{Mg} /$ creatinine ratio. There was no change when the urinary excretion was expressed as total $\mathrm{Mg}$ excretion but a significant change from 24.8 to $39.3 \mathrm{Mg}$ / creatinine ratio was found suggesting that a small increase of $\mathrm{Mg}$ concentration in drinking water for 6 weeks can improve body $\mathrm{Mg}$ status ${ }^{(110)}$.

Although there is no standardized protocol and the relative $\mathrm{Mg}$ deficits identified through its use may not represent the total body $\mathrm{Mg}$ deficit, this test has been useful and could be improved in the near future.

\section{Isotope balance studies}

The first analytical challenge when using stable isotopes to study the metabolic fate of $\mathrm{Mg}$ was the introduction of samples into a mass spectrometer. ${ }^{26} \mathrm{Mg}$ was chelated with tetramethylheptanedione, extracted and recovered by sublimation and introduced by solid probe into Mass Spectrometer for analysis at enrichment levels expected to be found in plasma, urine and faecal samples from subjects who had received this 
isotope as a tracer ${ }^{(111)}$. The accuracy of these analyses has continuously improved and allows a precise evaluation of intestinal $\mathrm{Mg}$ absorption, faecal excretion, and body retention. In addition, using kinetic data obtained from the analysis of blood samples it is now possible to undertake compartmental modelling to determine pool sizes and turnover rates. Stable isotopes are routinely used to study gastrointestinal functions but for $\mathrm{Mg}$, the availability and the cost of mass spectrometry measurements, the cost of the isotope and the rather complex protocol restrict the use of this method to research and not clinical studies. Among the studies published, stable isotopes have been used to evaluate the exchangeable $\mathrm{Mg}$ pool size in humans and to correlate these changes with $\mathrm{Mg}$ status. However, an 8-week $\mathrm{Mg}$ supplementation study of $366 \mathrm{mg}$ $\mathrm{Mg}$ per day in 24 year old healthy women did not show any modification in the size of the exchangeable $\mathrm{Mg}$ pools, but plasma ionized $\mathrm{Mg}$ and urinary excretion were significantly increased, while total plasma and erythrocyte levels were unchanged. In these healthy subjects, and under these experimental conditions, the study of exchangeable $\mathrm{Mg}$ pool size is not a sensitive biomarker of the variations of $\mathrm{Mg}$ status $^{(112)}$. To detect marginal $\mathrm{Mg}$ deficiency, an $11 \mathrm{ng}$ dose of ${ }^{26} \mathrm{Mg}$ was injected into 22 healthy subjects with a wide range of plasma $\mathrm{Mg}$ concentrations from 0.68 to $0.95 \mathrm{mmol} / \mathrm{l}$ (mean value $0.82 \pm 0.09 \mathrm{mmol} / \mathrm{l}$ ) and with adequate $\mathrm{Mg}$ intakes $(438 \pm$ and $464 \pm 138 \mathrm{mg}$ for men and women, respectively). This modified version of the loading test and $\mathrm{Mg}$ retention showed no correlation between the excretion of the isotopic label and muscle $\mathrm{Mg}$ concentration. Within 24 hours only $7.9 \%$ of the injected dose was excreted in the urine and the fraction excreted correlated with total urinary $\mathrm{Mg}$ excretion. In contrast to other loading tests, this dose was apparently insufficient to modify the size of the pools in subjects with marginal deficiency as defined by a range of $\mathrm{Mg}$ muscle concentrations from 3.50 to $4.19 \mathrm{mmol} / 100 \mathrm{~g}$ fat free dried solids ${ }^{(113)}$. Using double labelled $\mathrm{Mg}$ in healthy adult men, ${ }^{26} \mathrm{Mg}$ given orally and ${ }^{25} \mathrm{Mg}$ injected intravenously, blood, urine and faeces were collected for 12 days to build a compartmental model of $\mathrm{Mg}$ kinetics. However, this analysis only enables the exploration of $25 \%$ of the total body pool i.e. that which exchanges rapidly from the plasma compartment with two extra-plasma pools ${ }^{(10)}$.

\section{Physiological activities}

Biomarkers such as ferritin for iron have not been found for $\mathrm{Mg}$. It has been suggested that potential $\mathrm{Mg}$ markers could include $\mathrm{Na} / \mathrm{K}$ ATPase, thromboxane $\mathrm{B}_{2}$, C-reactive protein and endothelin-1, but other biomarkers are needed ${ }^{(3)}$. Because of the ubiquitous role of $\mathrm{Mg}$ and the interactions of other minerals such as calcium, the identification of a specific marker of $\mathrm{Mg}$ deficiency is challenging. $\mathrm{Mg}$ has been shown to be associated with various physiological responses such as blood pressure, but in this case known parameters, such as calcium, and additional unknown factors will also affect blood pressure. Therefore, the relationship between intracellular free $\mathrm{Mg}$ and diastolic blood pressure cannot be a marker of $\mathrm{Mg}$ status ${ }^{(114)}$. The activities of alkaline phosphatase and creatine kinase, two Mg-requiring enzymes, have been evaluated in relation to plasma and erythrocyte $\mathrm{Mg}$ concentration in rats to determine their usefulness as indices of $\mathrm{Mg}$ status ${ }^{(115)}$.
The results showed that plasma $\mathrm{Mg}$ concentration is the most useful indicator of $\mathrm{Mg}$ status. A very strong correlation was observed between plasma and bone concentrations. Other sensitive markers of deficiency may be developed through the study of gene expression, which was shown in animal experiments to change with $\mathrm{Mg}$ deficiency ${ }^{(116)}$.

\section{Ex vivo or in vitro cellular methods}

A new in vitro blood load test has been proposed to assess $\mathrm{Mg}$ status using stable isotopes. Blood cells were isolated and incubated with ${ }^{25} \mathrm{Mg}$ and it was proposed that high uptake would be triggered by $\mathrm{Mg}$ deficiency. The uptake in human erythrocytes was low compared to rat erythrocytes and higher enrichments were obtained for human lymphocytes and platelets. Thus, these latter cells seem more appropriate to test human $\mathrm{Mg}$ status using this in vitro system ${ }^{(117)}$. In vitro erythrocyte $\mathrm{Mg}$ fluxes were studied using stable isotopes in mice receiving $\mathrm{Mg}$ deficient diet and subsequently selected for their high or low erythrocyte $\mathrm{Mg}$ concentrations ${ }^{(38)}$. Although it is not possible to extrapolate the results obtained with severe $\mathrm{Mg}$ restriction in animals to the human situation, these in vitro studies can help to understand the role of TRPM channels in the specific regulation of intracellular $\mathrm{Mg}$ concentrations in blood cells and tissues. However, the authors correctly indicate that artificial erythrocyte $\mathrm{Mg}$ load tests performed in vitro may induce non-physiological cellular responses so any conclusions must be drawn with caution.

\section{TRPM (Transient Receptor Potential Melastatin) Channel}

Hypomagnesaemia, first described in $1968^{(118)}$ is an autosomal-recessive disorder of early infancy resulting in convulsions, muscle spasms or tetany. Extremely low serum $\mathrm{Mg}$ and low calcium levels are present, but the administration of high doses of $\mathrm{Mg}$ prevents permanent neurological damage and death. It was originally shown that the primary defect involved intestinal $\mathrm{Mg}$ absorption. TRPM6 protein has been identified and exhibits homology to TRPM7, which has been characterized as a calcium- and Mg-permeable ion channel regulated by Mg-ATP. The distribution of TRPM6 along the entire small intestine and colon as well as in distal tubule cells in the kidney shows how both the absorption and the excretion of $\mathrm{Mg}$ are controlled by this new family of cation channels. TRPM7 exhibits significant permeation to ionized $\mathrm{Mg}$ and is inhibited by cytosolic $\mathrm{Mg}$ ions and $\mathrm{Mg}$-ATP. This recent progress in epithelial $\mathrm{Mg}$ transport will certainly help in understanding the fine tuning of $\mathrm{Mg}$ homeostasis and its impact on disturbed $\mathrm{Mg}$ status ${ }^{(119-121)}$. The recent identification of TRPM channels and their role in hypomagnesaemia may eventually also result in chronic and mild $\mathrm{Mg}$ deficiency being explained by these specific transporters. It may also be possible in the future to accurately evaluate the transport capacity of $\mathrm{Mg}$ through these channels as a diagnostic of the risk for $\mathrm{Mg}$ deficiency.

\section{Conclusions}

A similar review of tests used to assess $\mathrm{Mg}$ status written 17 years ago concluded that there was no test that could readily be used in clinical medicine to assess the total body $\mathrm{Mg}$ 
status of a patient. Although intense research activities have been dedicated to $\mathrm{Mg}$, the difficulties of accessing total body $\mathrm{Mg}$, and its main two compartments, namely bone and muscle, mean that today there is still no simple, rapid, and accurate laboratory test to indicate total body $\mathrm{Mg}$ status in human. However, taking into account all the more recent investigations, although serum $\mathrm{Mg}<0.75 \mathrm{mmol} / \mathrm{l}$ still remains a useful measurement for severe deficiency, for values between 0.75 and $0.85 \mathrm{mmol} / \mathrm{l}$, a loading test must be performed to identify the deficient subjects. Loading tests appear to be the gold standard for $\mathrm{Mg}$ status but patients with disturbed kidney and intestinal functions should be excluded when the dose is given orally. There is also a need to reach a consensus on a standardized protocol to be used in order to compare results from different clinical units. Urinary $\mathrm{Mg}$ cannot replace the loading test as it does not reflect $\mathrm{Mg}$ status. Other cellular $\mathrm{Mg}$ measurements, such as total or ionized $\mathrm{Mg}$ are often equivocal and more research and systematic evaluations are needed. Muscle $\mathrm{Mg}$ appears to be a good marker but biopsies limit the use of this measurement to research. Bone, the most important $\mathrm{Mg}$ compartment cannot be used because of the invasiveness of the sampling and variations in measured $\mathrm{Mg}$ concentrations. The development of new and non invasive techniques such as NMR or ex vivo studies could in the future provide valuable tools for performing routine analyses of ionized $\mathrm{Mg}$ in tissues. With the development of molecular biology approaches and the recent discovery of TRPM channels, new, sensitive and fast evaluation of $\mathrm{Mg}$ status in humans may be developed in the near future.

\section{References}

1. Saris N-EL, Mervaala E, Karppanen H, Khawaja JA \& Lewenstam A (2000) Magnesium. An update on physiological, clinical and analytical aspects. Clin Chim Acta 294, 1-26.

2. Elin RJ (1991) Laboratory tests for the assessment of magnesium status in humans. Magnes Trace Elem 92, $172-181$.

3. Franz KB (2004) A functional biological marker is needed for diagnosing magnesium deficiency. $J$ Am Coll Nutr 23, $738 \mathrm{~S}-741 \mathrm{~S}$.

4. Arnaud MJ (1977) Autoradiographic study in the rat of the transit of magnesium from mineral water. Acta Pharmacologica et Toxicologica 21, 154-155.

5. Danielson BG, Johansson G \& Ljunghall S (1979) Magnesium metabolism in healthy subjects. Scand J Urol Nephrol Suppl 51, 49-73.

6. Avioli LV \& Berman M (1966) $\mathrm{Mg}^{28}$ kinetics in man. J Appl Physiol 21, 1688-1694.

7. Watson WS, Hilditch TE, Horton PW, Davies DL \& Lindsay R (1979) Magnesium metabolism in blood and the whole body in man using ${ }^{28}$ magnesium. Metabolism 28, 90-95.

8. Gold SW, Riediger H, Matthes S, Kuhn D, Graef V, Temme H, Katz N \& Roka L (1991) Homeostasis of magnesium in man after an oral supplementation: results of a placebo-controlled blind study. In Magnesium. A Relevant Ion, pp. 227-236 [B Lasserre and J Durlach, editors]. London: John Libbey.

9. Abrams SA \& Ellis KJ (1998) Multicompartmental analysis of magnesium and calcium kinetics during growth: relationships with body composition. Magnes Res 11, 307-313.

10. Sabatier M, Pont F, Arnaud MJ \& Turnlund JR (2003) A compartmental model of magnesium metabolism in healthy men based on two stable isotope tracers. Am J Physiol Regul Integr Comp Physiol 285, R656-R663.

11. Dewitte K, Stöckl D, Van de Velde M \& Thienpont LM (2000) Evaluation of intrinsic and routine quality of serum total magnesium measurement. Clin Chim Acta 292, 55-68.

12. Alfrey AC, Miller NL \& Butkus D (1974) Evaluation of body magnesium stores. $J$ Lab Clin Med 84, 153-162.

13. Arnold A, Tovey J, Mangat P, Penny W \& Jacobs S (1995) Magnesium deficiency in critically ill patients. Anaesthesia 50, 203-205.

14. Fiser RT, Torres A Jr, Butch AW \& Valentine JL (1998) Ionized magnesium concentrations in critically ill children. Crit Care Med 26, 2048-2052.

15. Emelyanov A, Fedoseev G \& Barnes PJ (1999) Reduced intracellular magnesium concentrations in asthmatic patients. Eur Respir J 13, 38-40.

16. Lukaski HC \& Nielsen FH (2002) Dietary magnesium depletion affects metabolic responses during submaximal exercise in postmenopausal women. J Nutr 132, 930-935.

17. Woodard JA, Shannon M, Lacouture PG \& Woolf A (1990) Serum magnesium concentrations after repetitive magnesium cathartic administration. Am J Emerg Med 8, 297-300.

18. Eibl NL, Kopp H-P, Nowak HR, Schnack CJ, Hopmeier PG \& Schernthaner G (1995) Hypomagnesemia in Type II diabetes: effect of a 3-month replacement therapy. Diabetes Care 18, $188-192$.

19. Wälti MK, Zimmermann MB, Spinas GA \& Hurrell RF (2003) Low plasma magnesium in type 2 diabetes. Swiss Med Wkly 133, 289-292.

20. Corica F, Allegra A, Ientile R \& Buemi M (1997) Magnesium concentration in plasma, erythrocytes, and platelets in hypertensive and normotensive obese patients. Am J Hypertens $\mathbf{1 0}$ $1311-1313$.

21. Gajos G, Solarska K, Siembab L, Nessler B, Nessler J, Stepniewski M \& Piwowarska W (1998) The importance of magnesium depletion in end stage heart disease and the efficacy of its acute intravenous supplementation with magnesium ascorbate. Proceedings for the XIIIth World Congress of Cardiology, Rio de Janeiro, Brazil, April 26-30, Monduzzi Editore, pp. 587-591.

22. Sjögren A, Florén CH \& Nilsson A (1988) Evaluation of magnesium status in Crohn's disease as assessed by intracellular analysis and intravenous magnesium infusion. Scand J Gastroenterol 23, 555-561.

23. Kazaks AG, Uriu-Adams JY, Albertson TE \& Stern JS (2006) Multiple measures of magnesium status are comparable in mild asthma and control subjects. J Asthma 43, 783-788.

24. Fox CH, Ramsoomair D, Mahoney MC, Carter C, Young B \& Graham R (1999) An investigation of hypomagnesemia among ambulatory urban African Americans. J Fam Pract 48, 636-639.

25. Bock JL, Wenz B \& Gupta RK (1985) Changes in intracellular $\mathrm{Mg}$ adenosine triphosphate and ionized $\mathrm{Mg}^{2+}$ during blood storage: detection by $31 \mathrm{P}$ nuclear magnetic resonance spectroscopy. Blood 65, 1526-1530.

26. Deuster PA, Trostmann UH, Bernier LL \& Dolev E (1987) Indirect vs direct measurement of magnesium and zinc in erythrocytes. Clin Chem 33, 529-532.

27. Nadler JL, Malayan S, Luong H, Shaw S, Natarajan RD \& Rude RK (1992) Intracellular free magnesium deficiency plays a key role in increased platelet reactivity in Type II diabetes mellitus. Diabetes Care 15, 835-841.

28. Gürlek A, Bayraktar M \& Özaltin N (1998) Intracellular magnesium depletion relates to increased urinary magnesium loss in Type I diabetes. Horm Metab Res 30, 99-102.

29. Engelen W, Bouten A, De Leeuw I \& De Block C (2000) Are low magnesium levels in type 1 diabetes associated with 
electromyographical signs of polyneuropathy? Magnes Res 13, 197-203.

30. Simşek E, Karabay M \& Kocabay K (2005) Assessment of magnesium status in newly diagnosed diabetic children: measurement of erythrocyte magnesium level and magnesium tolerance testing. Truk J Pediatr 47, 132-137.

31. Thomas J, Millot JM, Sebille S, Delabroise AM, Thomas E, Manfait M \& Arnaud MJ (2000) Free and total magnesium in lymphocytes of migraine patients - effect of magnesiumrich mineral water intake. Clin Chim Acta 295, 63-75.

32. Cox IM, Campbell MJ \& Dowson D (1991) Red blood cell magnesium and chronic fatigue syndrome. The Lancet 337, $757-760$

33. Malon A, Brockmann C, Fijalkowska J, Rob P \& Maj-Zurawska M (2004) Ionized magnesium in erythrocytes - the best magnesium parameter to observe hypo- or hypermagnesemia. Clin Chim Acta 349, 67-73.

34. Darlu P, Rao DC, Henrotte JG \& Lalouel JM (1982) Genetic regulation of plasma and red blood cell magnesium concentrations in man. I. Univariate and bivariate path analyses. $A m$ J Hum Genet 34, 874-887.

35. Lalouel JM, Darlu P, Henrotte JG \& Rao DC (1983) Genetic regulation of plasma and red blood cell magnesium concentration in man. II. Segregation analysis. Am J Hum Genet 35, 938-950.

36. Henrotte JG, Pla M \& Dausset J (1990) HLA- and H-2-associated variations of intra- and extracellular magnesium content. Proc Natl Acad Sci U S A 87, 1894-1898.

37. Feuillet-Coudray C, Coudray C, Wolf FI, Henrotte JG, Rayssiguier Y \& Mazur A (2004) Magnesium metabolism in mice selected for high and low erythrocyte magnesium levels. Metabolism 53, 660-665.

38. Feuillet-Coudray C, Trzeciakiewicz A, Coudray C, Rambeau M, Chanson A, Rayssiguier Y, Opolski A, Wolf FI \& Mazur A (2006) Erythrocyte magnesium fluxes in mice nutritionally and genetically low in magnesium status. Eur J Nutr 45, 171-177.

39. Basso LE, Ubbink JB \& Delport R (2000) Erythrocyte magnesium concentration as an index of magnesium status: a perspective from a magnesium supplementation study. Clin Chim Acta 291, 1-8.

40. Borella P, Facchinetti F, Rocchi E, Lorini R \& Bargellini A (1994a) Recommendations on the use of leukocytes to assess magnesium status. In Magnesium 1993, Chapter 8, pp. 71-75 [S Golf, D Dralle and L Vecchiet, editors]. London: John Libbey Ltd.

41. Borrella P, Bargellini A \& Ambrosini G (1994b) Magnesium supplementation in adults with marginal deficiency: response in blood indices, urine and saliva. Magnes Bull 16, 1-4.

42. Ryan MP \& Ryan MF (1979) Lymphocyte electrolyte alterations during magnesium deficiency in the rat. Ir J Med Sci 148, $108-109$.

43. Ryan MP, Ryan MF \& Counihan TB (1980) The effects of diuretics on lymphocyte magnesium and potassium. Acta Med Scand Suppl 647, 153-161.

44. Ryan MP, Ryan MF \& Counihan TB (1981) The effect of diuretics on lymphocyte magnesium and potassium. Acta Med Scand Suppl 647, 153-161.

45. Sjögren A, Floren CH \& Nilsson A (1986) Magnesium deficiency in IDDM related to level of glycosylated hemoglobin. Diabetes 35, 459-463.

46. Gallai V, Sarchielli P, Morucci P \& Abbritti G (1994) Magnesium content of mononuclear blood cells in migraine patients. Headache 34, 160-165.

47. Dyckner T \& Wester PO (1985) Skeletal muscle magnesium and potassium determinations: correlation with lymphocyte contents of magnesium and potassium. J Am Coll Nutr 4, $619-625$.
48. Kisters K, Tepel M, barenbrock M, Westermann G, Rahn KH, Zidek W \& Spieker C (1997) Magnesium status in normotensive and essential hypertensive patients: different cell models. Med Sci Res 25, 397-398.

49. Cohen L \& Kitzes R (1983) Magnesium sulphate and digitalistoxic arrhythmias. J Am Med Assoc 249, 2808-2810.

50. Sacks GS, Brown RO, Dickerson RN, Bhattacharya S, Lee PD, Mowatt-Larssen C, Ilardi G \& Kudsk KA (1997) Mononuclear blood cell magnesium content and serum magnesium concentration in critically ill hypomagnesemic patients after replacement therapy. Nutrition 13, 303-308.

51. Elin RJ \& Hosseini JM (1985) Magnesium content of mononuclear blood cells. Clin Chem 31, 377-380.

52. Corica F, Ientile R, Allegra A, Romano G, Cangemi F, Di Benedetto A, Buemi M, Cucinotta D \& Ceruso D (1996) Magnesium levels in plasma, erythrocyte, and platelet in hypertensive and normotensive patients with type 2 diabetes mellitus. Biol Trace Elem Res 51, 13-21.

53. Allegra A, Corsonello A, Buemi M, D'Angelo R, Di Benedettot A, Bonanzinga S, Cucinotta D, Ientile R \& Corica F (1997) Plasma, erythrocyte and platelet magnesium levels in type 1 diabetic patients with microalbuminuria and clinical proteinuria. J Trace Elements Med Biol 11, 154-157.

54. Resnick LM, Gupta RK, Bhargava KK, Gruenspan H, Alderman MH \& Laragh JH (1991) Cellular ions in hypertension, diabetes, and obesity. A nuclear magnetic resonance spectroscopic study. Hypertension 17, 951-957.

55. Rubenowitz E, Landin K \& Rylander R (1994) Magnesium in drinking water and in skeletal muscle and sublingual cells. Magnes Bull 16, 81-86.

56. Caddell JL \& Scheppner R (1978) The postmortem diagnosis of magnesium deficiency: studies in an animal model for the human infant. J Forensic Sci 23, 335-344.

57. Caddell JL, Heineman E \& Reed GF (1984) An evaluation of the parenteral magnesium load test in weanling rats. $J$ Nutr 114, $1260-1265$.

58. Guillard O, Mettey R, Lecron JC \& Pineau A (1992) Congenital hypomagnesemia: alternative to tissue biopsies for monitoring body magnesium status. Clin Biochem 25, $463-465$.

59. Alfrey AC \& Miller NL (1973) Bone magnesium pools in uremia. J Clin Invest 52, 3019-3027.

60. Jeppesen BB (1986) Magnesium status in patients with acute myocardial infarction: a pilot study. Magnesium 5, 95-100.

61. Fiaccadori E, Del Canale S, Coffrini E, Melej R, Vitali P, Guariglia A \& Borghetti A (1988) Muscle and serum magnesium in pulmonary intensive care unit patients. Crit Care Med 16, 751-760.

62. Gustafson T, Boman K, Rosenhall L, Sandström T \& Wester PO (1996) Skeletal muscle magnesium and potassium in asthmatics treated with oral beta 2 -agonists. Eur Respir $J$ 9, 237-240.

63. Landin K, Bonevik H, Rylander R \& Sandström BM (1989) Skeletal muscle magnesium and drinking water magnesium level. Magnes Bull 11, 177-179.

64. Ladefoged K \& Hagen K (1988) Correlation between concentrations of magnesium, zinc, and potassium in plasma, erythrocytes and muscle. Clin Chim Acta 177, 157-166.

65. Clague JE, Edwards RHT \& Jackson MJ (1992) Intravenous magnesium loading in chronic fatigue syndrome. The Lancet 340, 124-125.

66. Brinley FJ \& Scarpa A (1975) Ionized magnesium concentration in axoplasm of dialyzed squid axons. FEBS Lett 15, $82-85$.

67. Brinley FJ, Scarpa A \& Tiffert T (1977) The concentration of ionized magnesium in barnacle muscle fibres. $J$ Physiol 266, $545-565$. 
68. Achilles W, Scheidt B, Hoppe H \& Cumme GA (1977) An ion exchange method to determine free metal concentrations, adapted for use in biological fluids: methods and determination of $\mathrm{Mg}^{2+}$. Acta Biol Med Ger 36, 17-28.

69. Grima JM \& Brand JD (1977) Activity and interference effects in measurement of ionized calcium with ion-selective electrodes. Clin Chem 23, 2048-2054.

70. Niemela JE, Snader BM \& Elin RJ (1996) Determination of ionized magnesium in platelets and correlation with selected variables. Clin Chem 42, 744-748.

71. Cecco SA, Hristova EN, Rehak NN \& Elin RJ (1997) Clinically important inter-method differences for physiologically abnormal ionized magnesium results. Am J Clin Pathol 108, 564-569.

72. Csako G, Rehak NN \& Elin RJ (1997) Falsely high ionized magnesium results by ion-selective electrode method in severe hypomagnesemia. Eur J Clin Chem Biochem 35, 701-709.

73. Cook LA \& Mimouni FB (1997) Whole blood ionized magnesium in the healthy neonate. $J$ Am Coll Nutr 16, 181-183.

74. Hristova EN, Rehak NN, Cecco S, Ruddel M, Herion D, Eckardt M, Linnoila M \& Elin RJ (1997) Serum ionized magnesium in chronic alcoholism: is it really decreased? Clin Chem 43, 394-399.

75. Huijgen HJ, Sanders R, Cecco SA, Rehak NN, Sanders GT \& Elin RJ (1999) Serum ionized magnesium: comparison of results obtained with three ion-selective analyzers. Clin Chem Lab Med 37, 465-470.

76. Corica F, Corsonello A, Ientile R, Cucinotta D, Di Benedettoet A, Perticone F, Dominguez LJ \& Barbagallo M (2006) Serum ionized magnesium levels in relation to metabolic syndrome in Type II diabetic patients. J Am Coll Nutr 25, 210-215.

77. Huijgen HJ, Sanders R, van Olden RW, Klous MG, Gaffar FR \& Sanders GTB (1998) Intracellular and extracellular blood magnesium fractions in hemodialysis patients; is ionized fraction a measure of magnesium excess? Clin Chem 44, 639-648.

78. Greenway DC, Hindmarsh JT, Wang J, Khodadeen JA \& Hébert PC (1996) Reference interval for whole blood ionized magnesium in a healthy population and the stability of ionized magnesium under varied laboratory conditions. Clin Biochem 29, 515-520.

79. Hoshino K, Ogawa K, Kitazawa R, Nakamura Y \& Uehara R (1998) Ionized magnesium level in whole blood of healthy Japanese children. Acta Paediatr Jpn 40, 116-121.

80. Millot JM, Sebille S, Beljebbar M, Peirera M, Delabroise AM, Sabatier M, Caron J, Manfait M \& Arnaud MJ (2001) Short-term effects of magnesium-rich natural mineral water intake by healthy volunteers on total and ionized magnesium concentrations in plasma and blood cells. J Trace Elem Exp Med 14, 329.

81. Gupta RK, Benovic JL \& Rose ZB (1978) The determination of free magnesium level in the human blood cell by ${ }^{31} \mathrm{P}$ NMR. J Biol Chem 253, 6172-6176.

82. Huskens K, Main M, Malloy CR \& Sherry AD (1997) The determination of magnesium in human blood plasma by 31P magnetic resonance spectroscopy using a macrocyclic reported ligand. Biochim Biophys Acta 1336, 434-444.

83. Wary C, Brillault-Salvat C, Bloch G, Leroy-Willig A, Roumenov D, Grognet JM, Leclerc JH \& Carlier PG (1999) Effect of chronic magnesium supplementation on magnesium distribution in healthy volunteers evaluated by 31P-NMRS and ion selective electrodes. Br J Clin Pharmacol 48, 655-662.

84. Halvorson HR, Vande Linde AMQ, Helpern JA \& Welch KMA (1992) Assessment of magnesium concentratoins by ${ }^{31} \mathrm{P}$ NMR in vivo. NMR in Biomed 5, 53-58.

85. Rosenstein DL, Ryschon TW, Niemela JE, Elin RJ, Balaban RS \& Rubinow DR (1995) Skeletal muscle intracellular ionized magnesium measured by 31P-NMR spectroscopy across the menstrula cycle. J Am Coll Nutr 14, 486-490.

86. Lodi R, Montagna P, Soriani S, Iotti S, Arnaldi C, Cortelli P, Pierangeli G, Patuelli A, Zaniol P \& Barbiroli B (1997) Deficit of brain and skeletal muscle bioenergetics and low brain magnesium in juvenile migraine: an in vivo ${ }^{31} \mathrm{P}$ magnetic resonance spectroscolpy interictal study. Pediatr Res 42, 866-871.

87. Silver BB (2004) Development of cellular magnesium nanoanalysis in treatment of clinical magnesium deficiency. $J \mathrm{Am}$ Coll Nutr 23, 732S-737S.

88. Combs DK, Goodrich RD \& Meiske JC (1982) Mineral concentrations in hair as indicators of mineral status: a review. J Anim Sci 54, 391-398.

89. Hall RF, Sanders WL, Bell MC \& Reynolds RA (1971) Effects of season and grass tetany on mineral composition of Hereford cattle hair. Am J Vet Res 32, 1613-1619.

90. Brochart M (1975) Delay and magnitude of plasma bone responses and of stable, residual, leachable hair fractions to two different levels of $\mathrm{K}, \mathrm{Na}, \mathrm{Ca}, \mathrm{Mg}, \mathrm{P}$ intake in rat. Ann Rech Vet 6, 337-344.

91. Assarian GS \& Oberleas D (1977) Effect of washing procedures on trace-element content of hair. Clin Chem 23, $1771-1772$.

92. Ng SY (1999) Hair calcium and magnesium levels in patients with Fibromyalgia: a case centre study. J Manipulative Physiol Ther 22, 586-593.

93. Kozielec T, Durska G, Karakiewicz B \& Kędzierska E (2004) Analysis of blood and hair to investigate the magnesium status of neonates and their mothers. Magnes Res 17, 85-89.

94. Kozielec T, Salacka A, Radomska K, Strecker D \& Durska G (2001) The influence of magnesium supplementation on magnesium and calcium concentrations in hair of children with magnesium shortage. Magnes Res 14, 33-38.

95. Vellar OD (1979) Composition of human nail substance. Am J Clin Nutr 23, 1272-1274.

96. Garland M, Morris JS, Rosner BA, Stampfer MJ, Spate VL, Baskett CJ, Willett WC \& Hunter DJ (1993) Toenail trace element levels as biomarkers: reproducibility over a 6-year period. Cancer Epidemiol Biomarkers Prev 2, 493-497.

97. Graham LA, Caesar JJ \& Burgen ASV (1960) Gastrointestinal absorption and excretion of $\mathrm{Mg}^{28}$ in man. Metabolism 9, 646-659.

98. Ryzen E, Elbaum N, Singer FR \& Rude RK (1985) Parenteral magnesium tolerance testing in the evaluation of magnesium deficiency. Magnesium 4, 137-147.

99. Rujner J, Socha J, Syczewska M, Wojtasik A, Kunachowicz H \& Stolarczyk A (2004) Magnesium status in children and adolescents with celiac disease without malabsorption symptoms. Clin Nutr 23, 1074-1079.

100. Hébert P, Mehta N, Wang J, Hindmarsh $\mathrm{T}$, Jones $\mathrm{G}$ \& Cardinal P (1997) Functional magnesium deficiency in critically ill patients identified using a magnesium-loading test. Crit Care Med 25, 749-755.

101. Manuel y Keenoy B, Moorkens G, Vertommen J, Noe M, Nève J \& De Leeuw I (2000) Magnesium status and parameters of the oxidant-antioxidant balance in patients with chronic fatigue: effects of supplementation with magnesium. J Am Coll Nutr 19, 374-382.

102. Rob PM, Dick K, Bley N, Seyfert T, Brinckmann CH, Höllriegel V, Friedrich HJ, Dibbelt L \& Seelig MS (1999) Can one really measure magnesium deficiency using the short-term magnesium loading test? J Intern Med 246, 373-378.

103. Gullestad L, Midtvedt K, Dolva LO, Norseth J \& Kjekshus J (1994) The magnesium loading test: reference values in healthy subjects. Scand J Clin Lab Invest 54, 23-31.

104. Nielsen FH, Milne DB, Gallagher S, Johnson L \& Hoverson B (2007) Moderate magnesium deprivation results in calcium 
retention and altered potassium and phosphorus excretion by postmenopausal women. Magnes Res 20, 19-31.

105. Holm CN, Jepsen JM, Sjogaard G \& Hessov I (1979) A magnesium load test in the diagnosis of magnesium deficiency. Hum Nutr Clin Nutr 41C, 301-306.

106. Rasmussen HS, McNair P, Goransson L, Balsolv S, Larsen OG \& Aurup P (1988) Magnesium deficiency in patients with ischemic heart disease with and without acute myocardial infarction uncovered by an intravenous loading test. Arch Intern Med 148, 329-332.

107. Goto K, Yasue H, Okumura K, Matsuyama K, Kugiyama K, Miyagi H \& Hijashi T (1990) Magnesium deficiency detected by intravenous loading tests in variant angina pectoris. Am J Cardiol 65, 709-712.

108. Gullestad L, Nes M, Ronneberg R, Midtvedt K, Falch D \& Kjekshus J (1994a) Magnesium status in healthy free-living elderly Norvegians. J Am Coll Nutr 13, 45-50.

109. Mazur A, Felgines C, Feillet C, Boirie Y, Bellanger J, Beaufrère B, Gueux E, Rock E \& Rayssiguier Y (1997) Parenteral magnesium loading test in the assessment of magnesium status in healthy adult French subjects. Magnesium 10, 59-64.

110. Rubenowitz E, Axelsson G \& Rylander R (1998) Magnesium in drinking water and body magnesium status measured using an oral loading test. Scand J Clin Lab Invest 58, 423-428.

111. Schwartz R \& Giesecke CC (1979) Mass spectrometry of a volatile $\mathrm{Mg}$ chelate in the measurement of stable $26 \mathrm{Mg}$ when used as a tracer. Clin Chim Acta 97, 1-8.

112. Feillet-Coudray C, Coudray C, Tressol J-Cl, Pépin D, Mazur A, Abrams S \& Rayssiguier Y (2002) Exchangeable magnesium pool masses in healthy women: effects of magnesium supplement. Am J Clin Nutr 75, 72-78.

113. Wälti $\mathrm{MK}$, Walcyyk $\mathrm{T}$, Wimmermann $\mathrm{MB}$, Fortunato $\mathrm{G}$, Weber M, Spinas GA \& Hurrell RF (2006) Urinary excretion of an intravenous $26 \mathrm{Mg}$ dose as an indicator of marginal magnesium deficiency in adults. Eur J Clin Nutr 60, 147-154.

114. Resnick LM, Gupta RK \& Laragh JH (1984) Intracellular free magnesium in erythrocytes of essential hypertension: relation to blood pressure and serum divalent cations. Proc Natl Acad Sci 81, 6511-6515.

115. Fischer PWF \& Giroux A (1991) An evaluation of plasma and erythrocyte magnesium concentration and the activities of alkaline phosphatase and creatine kinase as indicators of magnesium status. Clin Biochem 24, 215-218.

116. Petrault I, Zimowska W, Mathieu J, Bayle D, Rock E, Favier A, Rayssiguier Y \& Mazur A (2002) Changes in gene expression in rat thymocytes identified by cDNA array support the occurrence of oxidative stress in early magnesium deficiency. Biochim Biophys Acta 1586, 92-98.

117. Feillet-Coudray C, Coudray C, Gueux E, Mazur A \& Rayssiguier Y (2003) A new in vitro blood load test using a magnesium stable isotope for assessment of magnesium status. J Nutr 133, 1220-1223.

118. Paunier L, Radde IC, Kooh SW, Conen PE \& Fraser D (1968) Primary hypomagnesemia with secondary hypocalcemia in an infant. Pediatrics 41, 385-402.

119. Chubanov V, Waldegger S, Mederos y Schnitzler M, Vitzthum $\mathrm{H}$, Sassen MC, Seyberth HW, Konrad M \& Gudermann T (2004) Disruption of TRPM6/TRPM7 complex formation by a mutation in the TRPM6 gene causes by hypomagnesemia with secondary hypocalcemia. PNAS 101, 2894-2899.

120. Konrad M, Schlingmann KP \& Gudermann T (2004) Insights into the molecular nature of magnesium homeostasis. Am J Physiol Renal Physiol 286, F599-F605.

121. Voets T, Nilius B, Hoefs S, van der Kemp AWCM, Droogmans G, Bindels RJM \& Hoenderop JGJ (2004) TRPM6 forms the $\mathrm{Mg}^{2+}$ influx channel involved in intestinal and renal $\mathrm{Mg}^{2+}$ absorption. J Biol Chem 279, 19-25. 